\title{
Impact of Titanium Nanoparticles in Implants
}

\author{
Narendhran S*, Monisha D, Reshma K Nair, Sasikala N and Sasikumar S \\ Department of Biotechnology, India
}

*Corresponding author: Narendhran S, Department of Biotechnology, Sri Ramakrishna College of Arts and Science College, Coimbatore 641006, India Submission: 眥August 23, 2017; Published: 眥 October 20, 2017

\begin{abstract}
Bone imbed mistreatment metal plates are being improved to meet speedier osseointegration and an additional grounded bone insert interface. The goal of this summary is to offer a broad information regarding the pharmacological medicine examination of bone imbed mistreatment metal (Ti) nanoparticles. The going with paper essentially focuses on the parlous impacts of implant material and also the effect of their physical and compound properties on the treatment result. In spite of the means that metal remains the quality biomaterial for a protracted time, affectability happens. On these lines the extension within the metal concentrations that are gotten from the inserts could cause extreme or long material medical effects. In clinical examinations it's found that $0.6 \%$ of 1500 patient show metal ominously helpless reactions. Afterward, support in vitro and particularly organized in vivo clinical examinations and specific experiences are needed whereas overseeing metal installs in people to constrain the speed of material medical effects.
\end{abstract}

Keywords: Osseointegration; Titanium plates; Bone implants, Allergic reactions; Implant interface

\section{Introduction}

Titanium is the widely used metal that is used for orthopedic and dental implants because of its biocompatibility with human tissues, low costs and profound accessibility. The physical and chemical properties of implant materials have clinical impacts, thus used for implant treatment. These properties incorporate the microstructure of the implant material and make it biocompatible with tensile strength, quality, consumption, wear and crack resistance [1]. The materials that are used in the implants are fabricated structure or their natural properties they elicit when implanted [2]. The clinical survival rates for platinum implants and its medicinal purpose have made it the best quality material for creation of implants. Totally, different metal and metal composites such as gold, stainless steel are widely considered. In case of any harmful tissue responses occurred occasionally are undermine their clinical trials and created these materials out dated inside the osteo implants [3,4] (Figure 1).
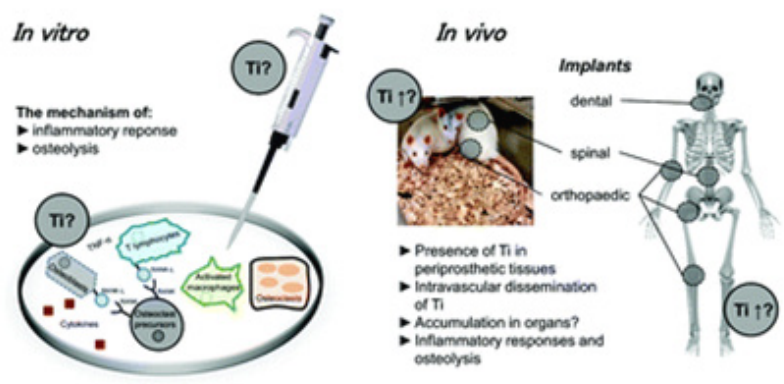

Figure 1

\section{Alloys of titanium and its characteristics (Table1)}

Table 1: Mechanical properties of industrially unadulterated titanium and its composites.

\begin{tabular}{|c|c|c|c|c|c|}
\hline Material & $\begin{array}{c}\text { Modulus } \\
\text { (GPa) }\end{array}$ & $\begin{array}{c}\text { Ultimate } \\
\text { Tensile } \\
\text { Strength } \\
\text { (MPa) }\end{array}$ & $\begin{array}{c}\text { Yield } \\
\text { Strength } \\
\text { (MPa) }\end{array}$ & $\begin{array}{c}\text { Density } \\
\text { (g/cc) }\end{array}$ & $\begin{array}{c}\text { Type of } \\
\text { Alloy }\end{array}$ \\
\hline $\begin{array}{c}\text { CpTi } \\
\text { grade I }\end{array}$ & 102 & 240 & 170 & 4.5 & $\alpha$ \\
\hline $\begin{array}{c}\text { CpTi } \\
\text { grade II }\end{array}$ & 102 & 345 & 275 & 4.5 & $\alpha$ \\
\hline $\begin{array}{c}\text { CpTi } \\
\text { grade III }\end{array}$ & 102 & 450 & 380 & 4.5 & $\alpha$ \\
\hline $\begin{array}{c}\text { CpTi } \\
\text { grade IV }\end{array}$ & 104 & 550 & 483 & 4.5 & $\alpha$ \\
\hline $\begin{array}{c}\text { Ti-6Al- } \\
4 \mathrm{~V}-\mathrm{ELI}\end{array}$ & 113 & 860 & 795 & 4.4 & $\alpha+\beta$ \\
\hline Ti-6Al-4V & 113 & 930 & 860 & 4.4 & $\alpha+\beta$ \\
\hline $\begin{array}{c}\text { Ti-6Al- } \\
7 \mathrm{Nb}\end{array}$ & 114 & $900-$ & $880-950$ & 4.4 & $\alpha+\beta$ \\
\hline $\begin{array}{c}\text { Ti-5Al- } \\
2.5 \mathrm{Fe}\end{array}$ & 112 & 1020 & 895 & 4.4 & $\alpha+\beta$ \\
\hline $\begin{array}{c}\text { Ti-15Zr- } \\
4 \mathrm{Nb}-2 \mathrm{Ta}- \\
0.2 \mathrm{Pd}\end{array}$ & $94-99$ & $715-919$ & $693-806$ & 4.4 & $\alpha+\beta$ \\
\hline $\begin{array}{c}\text { Ti-29Nb- } \\
\text { 13Ta- } \\
4.6 \mathrm{Zr}\end{array}$ & 80 & 911 & 864 & 4.4 & $\beta$ \\
\hline
\end{tabular}

As per the American Society for Testing and Materials, there are six clear kinds of titanium used as biomaterials. Out of these, four 
are economically perfect. The immaculate square measure called pure Grade I, Grade II, Grade III and Grade IV Ti. Economically pure Ti is likewise alluded to as pure Ti and proposals follow components enhance the mechanical properties of perfect Ti [3].

\section{Soluble titanium}

Frames of Titanium associated with aluminum and oxygen, its third type can be shaped by the biodegradation of metal amalgam inserts [5]. Implant discharges gold trash will experience consumption and discharge particulate part. These discharges exist in nursing passing few structures, mixture and ionic structure, natural reposition frames, inorganic metal oxides and salts. Consumption may produce solvent metal particles and may enter the dissemination of the blood and tumor. It might cause increased risk, pathogen or rot [6-9].

\section{Implant related metal sensitivity}

Innate immunity: Intrinsic unresponsive engraft jetsam and jetsam prompted aggravation is caused transcendently by macrophages, that reply to sterile (non-contaminated) engraft trash up regulating genius provocative interpretation factors (e.g., $\mathrm{NF}-\mathrm{\kappa B}$ ) and discharging incendiary chemokines, for instance, IL-8, white corpuscle chemotactic protein-1 (MCP-1), and MIP-1, and cytokines, for instance, IL-1 $\beta$, growth rot issue $\alpha$ (TNF- $\alpha$ ), and IL-6 [10]. At the purpose once particles initiate the inflammasome pathway, cells discharge and develop IL-1 $\beta$, IL-18, IL-33, and completely different cytokines and chemokines as takes after: Debris $\rightarrow$ Phagocytosis $\rightarrow$ Lysosome damage $\rightarrow$ Reactive Oxygen Species Inflammasome( $\left.\mathrm{NALP}_{3} / \mathrm{ASC}\right) \rightarrow$ Capasel $\rightarrow$ IL-1 $\beta$ (and alternative IL-1-family) cytokines and chemokines (MCP, etc.) [11].

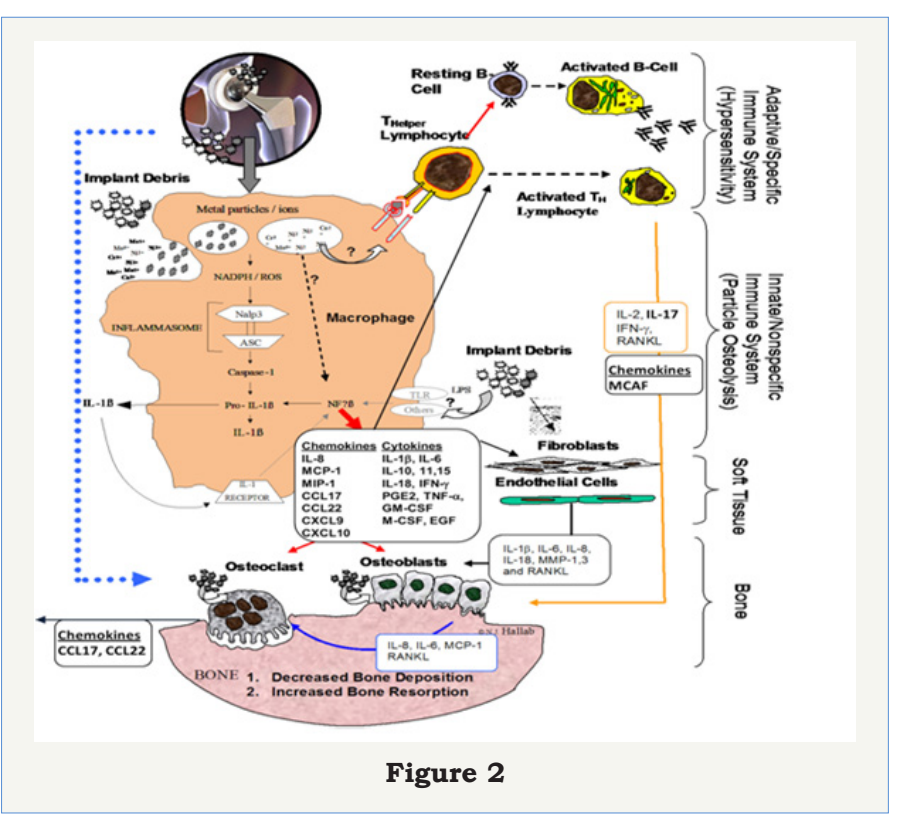

Adaptive immunity: All metal implants unleash implant dust through wear and corrosion $[11,12]$ and therefore the discharged metal ions, whereas not sensitizers on their own, will act as haptens, activating the system by forming complexes with native proteins. Nickel is that the most typical delayed sort hypersensitivity (DTH) sensitizer in humans followed by Cobalt and chromium $[13,14]$.
Lymphocytes are incontestable that they will assume a central half within the disappointment of a couple of forms of orthopaedic inserts [15]. The sub varieties of T-cells that command, engraft jetsam and jetsam connected reactions are T-partner (TH) cells. These TH reactions are delineating as a kind IV DTH reaction. DTH reaction to metal engraft garbage may be a versatile moderate cell-interceded reasonably reaction. Metal-antigen sharpened and motivated DTH T-cells discharge totally different chemokines, that enlist and enact macrophages for instance, IL-3 and GM-CSF (advances hematopoesis of granulocytes); leukocyte chemotactic initiating issue (advances taxis of monocytes toward zones of DTH actuation); IFN- $\gamma$ and TNF- $\beta$ (create varied impacts on near epithelial tissue cells encouraging penetration); and movement repressive issue (signals macrophages to remain within the neighbourhood the DTH response). A DTH self-sufficient reaction will create broad tissue damage. varieties of metal affectability testing, for instance, leucocyte amendment check associated fix testing (for skin responses) are the most intends to foresee/analyze those folks that can have an over the highest resistant reaction to metal presentation which will prompt untimely engraft failure [10]. TH1 cells are concerned as intervening-metal DTH reactions as delineate by creation of IFN- $\gamma$ and IL- 2 and to a lesser degree IL-17. DTH reaction connected chemokines fractalkine and CD40 show the probability of TH17 action (versus non-watched TH2 cell-interceded IL-10 reactions) [16,17]. Be that because it could, the chemokines engaged with TH1 reactions, for instance, MIG (monokine initiated by gamma antiviral drug, i.e., CXCL9) (Figure 2).

\section{Downfall of titanium}

Titanium plant break is connect extraordinary occasion with a found frequency stretching out from $1 / 3$ to six [18].

Potential explanations behind plan break can be of 3 imperative classes:

i. Embed layout

ii. Producing abandons

iii. Non-inert assault of the structure or physiological and biomechanical overload [3].

Ti plants as a rule bomb inferable from high cyclic stacking conveyance concerning peri-implant bone resorption; swollen turning minutes on additions and unavoidable metal tiredness and install break $[19,20]$.

\section{Toxicity response of titanium implants}

Lethal quality responses square measure another aspect of characteristic vaccinated start wherever cell demise and drive responses are found to be propelled by plant destruction and jetsam, where as there is a lots of reports by USA, et al. In addition, unsupportive is that the misidentification of metal particle motivated cell death as against the extra exact pyroptosis (provocative apoptosis) once ignitable cytokines is perceived. One particular instrument that has been known has been that of metal-started hypoxia-like responses [15]. The piece of cell demise, 
pyroptosis, and pyronecrosis in plant started bothering is so far diminishing and flawed.

\section{Result and Discussion}

Titanium and nuclear number 22 blends are the preeminent usually picked biomaterial for orthopedicals embeds due to their natural properties, consolidate delicacy, high compressive/versatility, and biocompatibility. Subsequently, there is a fundamental got the opportunity to like translatable, strong technique for surface change for nuclear number 22 orthopedically materials which will decrease surface association. That synthetic compound plan on the surface of nuclear number 22 additions could stifle or reduce bone tissue advancement affecting the attractive bond between present surface and physical cell. Associated biomaterials with surface segments , for example, substance creation, inner pore size, and body have facilitate affect on bone forming cell relocation, connection multiplication and bone forming cell separation [21]. The extended production of ROS and aerophilous nervousness will inimically impact the essentialness of epithelium cells and choke the development methodology.

\section{Conclusion}

Titanium is that the most normally utilized material for the making of inserts. This can be reinforced by brilliant and midand long run clinical outcomes. The subject of regardless of whether or not affectability and sensitivity to metallic component inserts is an issue of clinical significance or not remains a subject to be investigated. In addition, there is an expanding interest for a considerable measure of positive examination of engrafts destruction and jetsam prompted protein and chemokine trade to reduce this response reasonably. Rapidly brisk prototyping could be a novel accumulation methodology which will permit the formation of unambiguously outlined supplements that suit the genuine anatomical situation of every individual patient within material of call and speaks to a field that need to be investigated.

\section{References}

1. Francesca V, Gianluca G, Milena F, Giovanni L, Caterina AI, et al. (2017) Osseointegration is improved by coating titanium implants with nano structured thin film with titanium carbide and titanium oxides clustered around graphitic carbon. Material Science and Engineering 70: 264-271.

2. Heo DN, Ko WK, Lee HR, Lee SJ, Lee D, et al. (2016) Titanium dental implants surface-immobilized with gold nanoparticles as osteoinductive agents for rapid osseointegration. J Colloid Interface Sci 469: 129-137.

3. Rehman BO, Michael VS (2015) A critical review of dental implant materials with an emphasis on titanium versus zirconia. Materials 8: 932-958.
4. Sykaras N, Lacopino AM, Marker VA, Triplett RG, Woody RD (2000) Implant materials, designs, and surface tropographies: Their effect on osseointegration. A literature review. Int J Oral Maxillofac Implants 15(5): 675-690.

5. Golasik M, Herman M, Pietoszewski W (2016) Toxicological aspects of soluble titanium-a review of in vitro and in vivo studies. Metallomics 8: 1227-1242.

6. Watah JC (1996) Materials for endosseous dental implants. J Oral Rehabil 23(2): 79-90.

7. McCraken M (1998) Dental implant materials: Commercially pure titanium and titanium alloys. J Prosthodont 8(1): 40-43.

8. Lemons JE (1990) Dental implant biomaterials. J Am Dent Assoc 121(6): 716-719.

9. He Xiuliet (2016) Analysis of titanium and other plant metals in human jaw bones with dental implants- A case series study. Dental Materials 2768.

10. Revell PA, Jellie SE (1998) Interleukin 15 production by macrophages in the implant interface membrane of aseptically loosened joint replacements. J Mater Science Mater Med 9(12): 727-730.

11. Jacobs JJ (1994) Particulate wear in total hip replacement. NIH Consens Statement 12(5): 83-87.

12. Black J (1984) Systemic effects of biomaterials. Biomaterials 5(1): 11-18.

13. Yang J, Black J (1994) Competitive binding of chromium, cobalt and nickel to serum proteins. Biomaterials 15(5): 262-268.

14. Merritt K, Rodrigo JJ (1996) Immune response to synthetic materials. Sensitization of patients receiving orthopaedic implants. Clin Orthop Relat Res 326: 71-79.

15. Hallab NJ, Jacobs JJ (2017) Chemokines Associated with Pathologic Responses to Orthopedic Implant Debris. Front Endocrinol (Lausanne) 8: 5 .

16. Hallab NJ, Caicedo MFA, Jacobs JJ (2008) Th1 type lymphocyte reactivity to metals in patients with total hip arthroplasty. J Orthop Surg 3: 6.

17. Hercus B, Revell PA (2001) Phenotypic characteristics of T lymphocytes in the interfacial tissue of aseptically loosened prosthetic joints. J Mater Sci Mater Med 12(10/12): 1063-1067.

18. Thomas JB (1996) An analysis and management of fractured implants: A clinical report. Int J Oral Maxillofac. Implants 11(5): 660-666.

19. Tolman DE, Laney WR (1992) Tissue integrated prosthesis complications. Int J Oral Maxillofac Implants 7(4): 477-484.

20.Virdee P, Bishop K (2007) A review of the aetiology and management of fractured dental implants and a case report. Br Dent J 203: 461-466.

21. Piattelli A, Piattelli M, Scarano M, Montesani L (1998) Light and scanning electron microscopic report of four fractured implants. Int J Oral Maxillofac Implants 13(4): 561-564. 